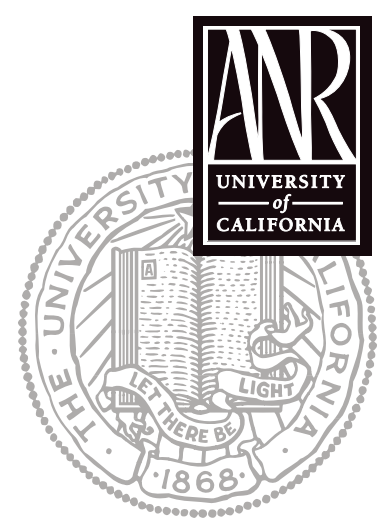

UNIVERSITY OF CALIFORNIA

Division of Agriculture and Natural Resources http://anrcatalog.ucdavis.edu

\title{
Genetic Engineering and Animal Agriculture
}

ALISON L. VAN EENENNAAM, Extension Specialist, Animal Genomics and Biotechnology, Department of Animal Science, University of California, Davis

\section{Have I ever eaten a genetically engineered animal?}

No. Genetically engineered (also known as transgenic) animals are those that carry and transmit one or more copies of a recombinant DNA sequence (i.e., a DNA sequence produced in a laboratory using in vitro techniques). Usually this DNA directs the production of a novel protein in the animal. Although many food animal species have been genetically engineered in research settings (e.g., cows, sheep, chickens, pigs, fish), no genetically engineered animals have been approved for use as human food in the United States.

The Food and Drug Administration's Center for Veterinary Medicine (CVM) asserts primary jurisdiction over genetically engineered animals as they are federally regulated under the Food, Drug, and Cosmetics Act. Developers of genetically engineered animals file investigational applications requesting approval for gene-based modifications. After providing adequate safety data, the sponsor may request approval for these animals to be used for food or for processing into animal feed components. Since 1995, a company called AquaBounty has been working to generate the data required for the approval of genetically engineered growth-enhanced Atlantic salmon that is capable of growing 4 to 6 times faster (but not larger) than standard salmon grown under the same conditions (Cook et al. 2000).

In addition to ensuring food safety, the FDA also evaluates environmental risks posed by transgenic animals, as directed by the National Environmental Policy Act (NEPA). Under NEPA, federal agencies are obligated to cooperate with other involved federal agencies. In the case of the AquaBounty transgenic salmon, this cooperation includes involvement of the U.S. Fish and Wildlife Service and the National Marine Fisheries Service in the development of a scientifically based environmental risk assessment.

\section{What about GloFish?}

One genetically engineered animal, a fluorescent red zebrafish called GloFish, is commercially available in the United States. The FDA decided not to regulate GloFish because tropical fish pose no threat to the food supply and there is no evidence that GloFish pose any greater threat to the environment than their widely sold unmodified counterparts. However, California's Fish and Game Commission decided to prevent the sale of these transgenic zebrafish to aquarium hobbyists in the state. A permit is required to import, transport, possess, rear, or conduct research on genetically engineered fish in California. Such fish must be kept in closed-water systems or in a system that prevents the inadvertent release of live fish, and access to facilities containing genetically engineered fish must be restricted.

The California Fish and Game Commission holds a public hearing for each permit application to ensure that any permit granted is in the public's best interest. The decision to ban GloFish was not based on evidence of environmental risk, since the zebrafish is a tropical species that cannot tolerate cold well enough to reproduce in California waters. Instead, the decision was based on ethical grounds. In reaching this decision one of the commissioners stated that he did not consider it to be right 
to produce a new genetically engineered organism "just to be a pet" (Thompson 2003). A unique aspect of the genetic engineering of animals is that animals hold a special place in our society. They are sentient living beings and are often treasured members of families. As a result of personal beliefs, some people oppose the human use of animals for any purpose, while others have specific concerns about the impacts of genetic engineering on animal health and welfare, and still others object to the use of terminology such as "transgenic animal bioreactors" to describe genetically engineered animals that produce human therapeutic or industrial proteins.

\section{What is the greatest science-based concern associated with the genetic engineer- ing of animals?}

A recent report by the National Academy of Sciences stated that environmental issues were the greatest science-based concern associated with the genetic engineering of animals (National Research Council 2002). Of high concern is the possibility that genetically engineered organisms, particularly fish and insects, may escape confinement and become feral. The actual environmental risk posed by each species-transgene combination depends on a number of factors, including the containment strategy, species mobility, ability to become feral, genotype by environmental interactions, and the stability of the receiving community. For example, it is much easier to contain a genetically engineered cow than a fish. Food safety concerns about transgenic animals are similarly case-specific, depending on the attributes of the recombinant protein and whether the animal is intended to be used as food or to be a producer of recombinant protein for a pharmaceutical or industrial application.

\section{Does recombinant bovine somatotropin (rBST) make cows genetically engineered?}

One product of genetic engineering that is currently being used in animal agriculture is recombinant bovine somatotropin (rBST) derived from genetically engineered bacteria. When administered to lactating cows, this protein increases milk production. It is widely used throughout the U.S. dairy industry and was approved by the FDA in 1993 following extensive safety testing by numerous medical associations and scientific societies (Bauman 1999). Cows that are administered rBST are being treated with a protein, and this does not modify the DNA of cows in any way.

\section{Why genetically engineer animals?}

Although to date the only genetically engineered animal available on the market (except in California, where it is banned) is a glowing red aquarium fish, genetic engineering has the potential to address other more vital societal interests. The University of Guelph has developed a genetically engineered pig, coined the Enviropig, that can better utilize feed phosphorus and thus generate "low-phosphorus manure" (Golovan et al. 2001); phosphorus from animal manure can contribute to surface water pollution. Genetic engineering technology is also being tested as a means to improve the disease and parasite resistance of domestic livestock. For example, scientists are currently working on producing cattle resistant to bovine spongiform encephalopathy (BSE) (Kuroiwa et al. 2004).

At this point it seems unlikely that genetically engineered animals will find widespread use for the improvement of most livestock production traits. One of the reasons for this is that agriculturally relevant traits such as growth tend to be controlled by many genes, making it difficult to select or predict how the expression of one or two recombinant proteins might influence these complex performance traits. Additionally, traditional genetic selection techniques achieve reliable and consistent rates of genetic improvement for most livestock species and do not require the investment, risk, and 
time involved with the production and regulatory approval of genetically engineered organisms. In the short term it seems more likely that genetic engineering will be used mostly for biomedical applications. Genetically engineered proteins have been made and secreted in milk, blood, eggs, urine, and semen of livestock, although to date most commercial production favors the mammary gland (Houdebine 2000). "Transplantation-friendly" genetically engineered pigs are currently being developed to help alleviate the critical shortage of organs for human transplantation (Takahagi et al. 2005).

\section{PERSPECTIVE}

There are currently no genetically engineered food animals on the market in the United States. Before such animals are approved for sale, they will have to pass a human and environmental safety evaluation as a part of the FDA regulatory approval process. The risks and benefits associated with this technology depend on several factors, including the species under consideration and the genetically engineered protein that is being expressed. The animal biotechnology industry faces a variety of scientific, regulatory, ethical, and public acceptance issues, and it remains to be seen whether any of the potential benefits are great enough to outweigh the risks and costs involved in the development and approval of genetically engineered animals.

\section{REFERENCES}

Bauman, D. E. 1999. Bovine somatotropin and lactation: From basic science to commercial application. Domestic Animal Endocrinology 17:101-116.

Cook, J. T., M. A. McNiven, G. F. Richardson, and A. M. Sutterlin. 2000. Growth rate, body composition and feed digestibility/conversion of growth-enhanced transgenic Atlantic salmon (Salmo salar). Aquaculture 188:15-32.

Golovan, S. P., R. G. Meidinger, A. Ajakaiye, M. Cottrill, M. Z. Wiederkehr, D. J. Barney, C. Plante, J. W. Pollard, M. Z. Fan, M. A. Hayes, J. Laursen, J. P. Hjorth, R. R. Hacker, J. R. Phillips, and C. W. Forsberg. 2001. Pigs expressing salivary phytase produce low-phosphorus manure. Nature Biotechnology 19:741-745.

Houdebine, L. M. 2000. Transgenic animal bioreactors. Transgenic Research 9:305-320.

Kuroiwa, Y., P. Kasinathan, H. Matsushita, J. Sathiyaselan, E. J. Sullivan, M. Kakitani, K. Tomizuka, I. Ishida, and J. M. Robl. 2004. Sequential targeting of the genes encoding immunoglobulin-mu and prion protein in cattle. Nature Genetics 36:775-780.

National Research Council. 2002. Animal biotechnology: Science-based concerns. Washington, D.C.: National Academies Press.

Takahagi, Y., T. Fujimura, F. Miyagawa, H. Nagashima, T. Shigehisa, R. Shirakura, and H. Murakami. 2005. Production of alpha 1,3-galactosyltransferase gene knockout pigs expressing both human decay-accelerating factor and Nacetylglucosaminyltransferase III. Molecular Reproduction and Development 71:331-338.

Thompson, D. 2003. California bans transgenic fish. Associated Press, Dec. 3. See MSN Web site, http://msnbc.msn.com/id/3660462/. 


\section{FOR MORE INFORMATION}

To order or obtain printed ANR publications and other products, visit the ANR Communication Services online catalog at http://anrcatalog.ucdavis.edu. You can also place orders by mail, phone, or FAX, or request a printed catalog of our products from:

University of California

Agriculture and Natural Resources

Communication Services

6701 San Pablo Avenue, 2nd Floor

Oakland, California 94608-1239

Telephone: (800) 994-8849 or (510) 642-2431

FAX: (510) 643-5470

E-mail inquiries: danrcs@ucdavis.edu

An electronic version of this publication is available on the ANR Communication Services Web site at http://anrcatalog.ucdavis.edu.

\section{Publication 8184}

(C) 2005 by the Regents of the University of California, Division of Agriculture and Natural Resources. All rights reserved.

The University of California prohibits discrimination or harassment of any person on the basis of race, color, national origin, religion, sex, gender identity, pregnancy (including childbirth, and medical conditions related to pregnancy or childbirth), physical or mental disability, medical condition (cancer-related or genetic characteristics), ancestry, marital status, age, sexual orientation, citizenship, or status as a covered veteran (covered veterans are special disabled veterans, recently separated veterans, Vietnam era veterans, or any other veterans who served on active duty during a war or in a campaign or expedition for which a campaign badge has been authorized) in any of its programs or activities. University policy is intended to be consistent with the provisions of applicable State and Federal laws.

Inquiries regarding the University's nondiscrimination policies may be directed to the Affirmative Action/Staff Personnel Services Director, University of California, Agriculture and Natural Resources, 300 Lakeside Drive, 6th Floor, Oakland, CA 94612-3550 (510) 987-0096. For a free catalog of other publications, call (800) 994-8849. For help downloading this publication, call (530) 297-4445.

To simplify information, trade names of products have been used. No endorsement of named or illustrated products is intended, nor is criticism implied of similar products that are not mentioned or illustrated.

This publication has been anonymously peer reviewed for technical accuracy by University of California scientists and other qualified professionals. This review process was managed by the ANR Associate Editor for Animal, Avian, Aquaculture, and Veterinary Sciences.

pr-11/05-SB/CR

ISBN 978-1-60107-334-1 